\title{
GOOD GOVERNANCE DALAM PENYELENGGARAAN PEMERINTAH DAERAH
}

\author{
Oleh: ${ }^{1}$ Junindra Martua \\ (Fakultas Hukum Universitas Asahan) \\ Email:junindra@gmail.com
}

\begin{abstract}
ABSTRAK
Otonomi daerah diletakkan sebagai jawaban was perkembangan keadaan, sekaligus memberi kewenangan yang luas, nyata dan bertanggung jawab kepada daerah secara proporsional dengan perwujudan Pengaturan, pembagian dan pemanfaatan sumber daya nasional serta perimbangan keuangan pusat dan daerah. Pemberian wewenang lebih luas bagi daerah membutuhkan prasyarat berupa propesionalitas dan integritas yang memadai. Kalau dua prasyarat ini tidak terpenuhi, maka otonomi daerah benar- benar bisa menjadi medium desentralisasi korupsi. Good governance harus ditegakkan, bukan saja oleh DPRD maupun lembaga pemerintah yang berkompeten dibidang pengawasan pembangunan, melainkan juga kontrol langsung oleh masyarakat agar pelaksanaan pemerintah daerah benar- benar dapat terwujud.

Kata Kunci: Good, Governance, Penyelenggaraan, Pemerintah, Daerah.
\end{abstract}

\section{ABSTRACT}

Regional autonomy is placed in response to developments in the situation, as well as giving broad, real and accountable authority to the regions in proportion to the realization of the regulation, distribution and utilization of national resources as well as the balance of central and regional finances. Granting wider authority to regions requires prerequisites in the form of adequate professionalism and integrity. If these two prerequisites are not fulfilled, then regional autonomy can really become a medium for decentralizing corruption. Good governance must be enforced, not only by the DPRD and competent government agencies in the field of development supervision, but also direct control by the community so that the implementation of local government can truly be realized.

Keywords: Good, Governance, Implementation, Government, Region. 


\section{A. PENDAHULUAN}

Sejak UU No. 32 Tahun 2004 Tentang Pemerintahan Daerah, dan UU No. 33 Tahun 2004 Tentang Perimbangan Keuangan Pusat dan Daerah disahkan, berbagai reaksi yang menyangkut kebijakan desentralisasi ini berkembang luas, dan banyak kalangan menilai inilah saatnya babak baru tentang otonomi Daerah.

Otonomi Daerah diletakkan seba gai jawaban atas perkembangan keadaan, sekaligus memberi kewenangan yang luas, nyata dan bertanggung jawab kepada daerah secara proporsional dengan perwujudan pengaturan, pembagian dan pemanfaatan sumber daya nasional serta perimbangan keuangan pusat dan daerah. Dengan demikian melalui otonomi daerah model baru ini ada solusi terhadap problema ketimbangan pusat-daerah, disintegrasi nasional, serta minimnya aspirasi masyarakat lokal.

Peletakan
pada

daerah kabupaten/kota menuntut konsekwensi adanya hak dan kewajiban daerah dalam bentuk pelayanan, dan kesejahteraan masyarakat yang semakin baik, pengembangan kehidupan demokrasi, keadilan, dan pemerataan serta pemeliharaan hubungan yang serasi antara pusat dan daerah serta antara daerah dalam rangka menjaga keutuhan Negara kesatuan Republik Indonesia.

\section{B. HASIL DAN PEMBAHASAN}

1. Prinsip Penyelenggaraan Pemda

Penyelenggaraan otonomi Daerah

didasarkan pada isi dan jiwa yang terkandung dalam pasal 18 UUD 1945 beserta penjelasannya dan ini menjadi pedoman dalam penyusunan UU No. 32 Tahun 2004. dengan pokok- pokok pikiran sebagai berikut :

- Sistem ketatanegaraan Indonesia wajib menjalankan prinsip pembagian kewenangan berdasarkan asas dekonsentrasi dan desentralisasi dalam kerangka Negara kesatuan Republik Indonesia.

- Daerah yang dibentuk berdasarkan asas desentralisasi dan dekonsentrasi adalah daerah propinsi, sedangkan daerah yang dibentuk berdasarkan asas desentralisasi adalah daerah kabupaten dan daerah kota.

- Daerah yang dibentuk dengan asas desentralisasi berwenang untuk menentukan dan melaksanakan kebijakan atas prakarsa sendiri berdasarkan aspirasi masyarakat.

Pembagian Daerah diluar Daerah propinsi dibagi habis kedalam Daerah otonom. dengan demikian, wilayah Administrasi yang berada dalam daerah kabupaten dan kata dijadikan otonom atau dihapus.

Kecamatan yang menurut UU No. 5 Tahun 1974 sebagai wilayah Administrasi dalam rangka dekonsentrasi, menurut undang-undang ini kedudukannya diubah menjadi perangkat daerah Kabupaten atau daerah kota.

Penyelenggaraan pemerintahan Daerah akan sangat kompleks dan problem.

Dilapangan banyak masalah yang sebe lumnya tidak terpikirkan pada saat penyu sunan konsep. Dengan demikian diperlukan semacam prinsip sebagai acuan dalam mengatasi masalah dilapangan.

Adapun prinsip penyelenggaraan pemerintahan daerah adalah :

a. Menggunakan asas desentralisasi, dekonsentrasi, dan tugas pembantuan;

b. Penyelenggaraan asas desentralisasi secara utuh dan bulat yang tidak dilaksanakan di 
Daerah kabupaten dan Daerah kota; dan

c. Asas tugas pembantuan yang dapat dilaksanakan di Daerah kabupaten, Daerah kota dan desa.

2. Pengelolaan Keuangan Daerah

Untuk menyelenggarakan otonomi

Daerah yang luas, nyata dan bertanggung jawab, diperlukan kewenangan dan kemampuan menggali sumber keuangan sendiri yang didukung oleh perimbangan keuangan antara pemerintah pusat dan daerah serta antara propinsi dan

kabupaten/kota yang merupakan persyaratan dalam sistem pemerintahan daerah.

Dalam menyelenggarakan otonomi daerah, kewenangan keuangan yang melekat pada setiap kewenangan pemerintah menjadi kewenangan daerah.

Selanjutnya penyelenggaraan tugas pemerintahan daerah dibiayai dari dan atas beban APBD dan APBN.

APBD ditetapkan dengan peraturan

daerah selambat-lambatnya satu bulan setelah ditetapkannya APBD. Perubahan APBD ditetapkan selambat-lambatnya tiga bulan sebelum tahun anggaran berakhir. Perhitungan APBD ditetapkan selambat-lambatnya tiga bulan setelah berakhirnya tahun anggaran yang bersangkutan.

Pembiayaan pelaksanaaan otonomi daerah menurut UU No. 33 Tahun 2004, dibedakan atas tiga jenis, yaitu :

a. Pengolahan dan pertanggung jawaban keuangan dalam pelaksanaan dekonsentrasi. Yaitu pembiayaan dalam rangka pelaksanaan dekonsentrasi yang disalur kan kepada gubernur melalui depertemen/lembaga pemerintah non depertemen yang bersangkutan. Kewenangan dan tanggung jawab sehubungan dengan pembiayaan dalam rangka pelaksanaan dekosentrasi, mengaku kepada peraturan peundang-undangan mengenai APBN dan pembendaharaan negara.

b. Pengolahan dan pertanggung jawaban keuangan dalam pelaksanaan tugas pembantuan. Pembiayaan dalam rang ka pelaksanaan tugas pembantuan disalurkan kepada daerah dan desa melalui depertemen/lembaga pemerintahan non departemen

yang menugaskannya. Per tanggung jawaban itu dilakukan oleh daerah dan desa kepada

pemerintah pusat melalui depertemen /lembaga pemerintahan non depertemen yang menugaskannya.

c. Pengolahan dan pertanggung jawaban Keuangan dalam pelaksanaan desentralisasi.

Semua penerimaan dan pengeluaran dalam rangka pelaksanaan desentrali sasi dicatat dan dikelola dalam APBD dan ditetapkan dengan peraturan daerah dan merupakan dokumen daerah. Sebagai con toh, pungutan Puskesma yang berfungsi sebagai penerimaan dalam rangka

pelaksanaan desentralisasi dan diadministrasikan APBD.

Sistem dan proses pengolahan keuangan daerah diatur dengan keputusan kepala daerah sesuai dengan peraturan daerah yang sistem dan prosedur pengolahannya meliputi :

- Struktur organisasi

- Dokumentasi, dan

- Prosedurterperincidalam pelaksanaanpengolahan keuangan

Tujuannya untuk mengoptimalkan efektifitas, efesiensi, dan keamanan. Selain itu, system produser tersebut harus dapat menyediakan informasi kepada pemerintah pusat secara akurat dan tepat waktu. 
3. Pilar Good Governance di Daerah Otonomi daerah merupakan jawaban kompromistis pemerintah pusat yang cukup jenial dari perspektif politik. Akan tetapi, dari dimensi ekonomi, ternyata masih banyak "pekerjaan rumah" yang harus dilakukan agar transportasi menuju pemberdayaan daerah tidak menjadi boomerang bagi kepentingan public.

Contultative Group on Indonesia (CGI) mengemukakan kekhawatirannya bahwa otonomi daerah bisa juga berarti desentralisasi korupsi (kompas, 2 November 2000). Kecemasan bahwa otonomi bisa menjadi medium transplantasi KKN dari pusat kedaerah, memang sangat wajar dikemukakan. Justru kecemasan tersebut seharusnya di jadikan sebagai early warning bagi kita untuk mengantisipasi sisi gelap implementasi kebijakan otonomi daerah.

Pemberian wewenang lebih luas bagi daerah membutuhkan prasyarat berupa propesionalitas dan integritas yang memadai. Kalau dua prasyarat ini tidak terpenuhi, maka otonomi daerah benarbenar bisa menjadi medium desentralisasi korupsi.

Bagi pemda, otonomi ibarat seke ping mata uang yang memiliki dua sisi. Ketika pemerintah di daerah memperoleh

kemandirian untuk membangun wilayahnya, pada saat yang sama muncul pula kewajiban untuk mempertanggungjawab kan efektifitas dan efisiensi kebijakan publik. Persoalannya menjadi rumit ketika penyelenggaraan pemerintah selama ini terselubungi oleh kabut KKN. Korupsi

dipahami sebagai virus yang membahayakan eksistensi sebuah negara.

Korupsi bukan saja menyebabkan birokrasi pemerintahan yang tidak efisien. Menurut Michael Johntson, kebanyakan korupsi menguntungkan orang-orang kaya, yang biayanya harus di bayar secara politik, sebagaimana juga secara materi, oleh kalangan miskin.

Korupsi bukan cuma pemberian uang suap kepada pejabat, tetapi juga meliputi transaksi-transaksi politik yang memperjualbelikan jabatan. Kenyataan ini memperkuat temuan Wade bahwa dibeberapa negara berkembang terdapat pasar untuk jabatan dalam birokrasi dimana terjadi transaksi politik yang menyalahgu nakan kepercayaan rakyat.

Dalam proses pemilihan kepala daerah misalnya, terdapat banyak indikasi adanya praktik money politics. Kecuali menyebabkan konplik jangka pendek, praktek money politics dalam pemilihan individu untuk memegang jabatan public seperti kepala daerah, dapat berdampak pada legitimasi pemerintahan dalam jangka panjang.

Korupsi di Indonesia diyakini sebagai virus yang sudah meluas dan mengesankan sebagai fenomena cultural. Bank Dunia pernah mensinyalir bahwa 20-30 persen dana pinjaman luar negeri untuk Indonesia terabsorbesi kedalam birokrasi yang berkultur korupsi. Persentasi menguapnya dana yang

dinyatakan Bank Dunia tersebut konsisten dengan sinyalemen $\mathrm{Su}$ mutro Djojohadikusumo bahwa high cost ecomotny di Indonesia mencapai 30-an persen.

Moctar Mas'oed dan Robert Klitz gaard menganggap posisi dominant birokrasi pemerintah sebagai sumber utama barang dan jasa, sebagai titik rentan ter jadinya korupsi dan kolusi. Dominasi ekonomi itu melibatkan Negara dalam transaksi-transaksi dalam jumlah besar dan frekuensi tinggi. Dalam transaksi tersebut, kepentingan Negara diwakilkan kepada seseorang atau sekelornpok pejabat.

4. Optimalisasi PAD

Pemberian wewenang lebih luas bagi daerah membutuhkan prasyarat urupa 
propesionalitas dan integritas yang memadai. Kalau dua prasyarat ini tidak terpenuhi, maka otonomi daerah benarbenar bisa menjadi medium desentralisasi korupsi. Bagi pemda otonomi ibarat sekeping mata uang yang memiliki dua sisi.

Ketika pemerimtah didaerah mem peroleh kemandirian untuk membangun wi layahnya, pada saat yang sama muncul pu la kewajiban untuk mempertanggung jawabkan efektifitas dan efisiensi kebijakan publik. Persolannya menjadi rumit ketika penyelenggara pemerintahan terselubungi noda KKN.

Oleh karena itu, kebanyakan daerah diukur kesiapannya mengimplemen tasikan otonomi berdasarkan proporsi PAD terhadap APBD. Proporsi tersebut berkisar antara 0,1 sampai 0,6 Artinya, kisaran kemampuan finansial daerah mem biayai pemerintahannya hanya 10 60 per sen dari kebutuhan pinansial yang ada.

Dalam banyak kasus, pemda masih menghadapi kendala seputar propesiona litas dan integritas. Kalau tidak siap, peng guliran otonomi daerah dapat memancing munculmya kasus KKN pada scope daerah dengan nilai nominal yang sangat besar.

F. Penegakan Good Governance

Efektifitas dan efisiensi pembangunan dalam kerangka otonomi memerlukan terpenuhinya prasyarat berupa tata cara pemerintahan yang baik dan bersih (good and clean governance).

Bukan cuma ditingkat lokal, tetapi juga pada skala nasional. Menuju praktik pemerintahan yang baik dan bersih, mekanisme kontrol terhadap pemda, baik dilakukan oleh lembaga legeslatif daerah maupun masyarakat secara langsung.

Good governance adalah cara dimana kekuasaan dilaksanakan dalam penguasaan sumberdaya ekonomi dan social suatu negara bagi kemajuan.
Terdapat hak eko nomi dan politik masyarakat didalam pembangunan, sehingga alokasi sumberdaya oleh negara dilakukan sebagai jaminan terhadap hak ekonomi dan politik tersebut.

Bank Dunia merekomendasikan empat hal penting untuk menuju good go vernance, yakni keterandalan, kerangka hukum yang efektif, inpormasi yang sejalan dengan transparansi dan tersedianya tenaga kerja terdidik.

Keterandalan good governance tak lepas dari permasalahan teknis seputar kwalitas birokrasi. Disadari bahwa problema mendasar yang sangat potensial menjadi hambatan efektifitas pelaksanaan otonomi daerah adalah clean government. Patologi birokrasi seperti nevotisme, kolusi dan korupsi berkombinasi dengan faktor-faktor kultural sebagai lahan penjalinan hubungan patron-klien yang mempertaruhkan kepentingan publik. Kendala-kendala struk tural dan kultural sulit teratasi secara tuntas selama masih ada kompromi dan toleransi terhadap perilaku devian pada birokrasi yang bersih.

Kerangka hukum yang efektif adalah menjamin terselenggaranya good governance. Dapat dibayangkan, bila sebu ah produk hukum tak mampu tampil seba gai pranata formal, maka berbagai hamba tan struktural dan kultural dalam birokrasi di daerah akan sulit dijinakkan.

Kecenderungan memberi toleransi terhadap prilaku menyimpang, karena bersentuhan langsung dengan kepentingan elit politik dan ekonomi, hanya akan memelihara bibit penyelewengan yang kronis. Hal in i diperparah bila mekanisme kontrol baik yang bersifat formal maupun inform] sudah mengalami penyempitan gerak.

Peran media masa dan presure group sangat dibutuhkan. Ketika terjadi semacam pemakiuman misal yang menjustifikasi praktik KKN, ada 
kecenderungan untuk menutup-nutupi hal yang sesungguhnya. Berbagai excuse dan pembenaran di buat untuk menipu masyarakat. Media masa dan kelompokkelompok penekan mengambil peran penting untuk menguak sesuatu y6ang diselubungi tersebut.

Dalam bingkai good governance, transparansi pelaksanaan pemerintahan serta peningkatan akses politik ekonomi masyarakat berpeluang memuncukkan situasi dialogis antara masyarakat dan negara sehingga meminimalisir kemungkinan ter jadinya akibat negatif dari otonomi daerah, seperti ketercabutan kelompok orang dari wilayah asalnya (displacement) yang memunculkan orang miskin baru, ketersisihan dari sistem sosial (disempowerment) dan pemiskinan relatif maupun absolut.

Good governance, teutama pada daerah, menjadi kunci mengantisipasi praktik merebabnya mega korupsi di daerah. Disamping berpeluang memberi kontribusi bagi eliminasi praktik yang tak sehat, aspek good governance juga dapat memper baiki mekanisme kontrol terhadap pemda, baik oleh lembaga legeslatif maupun masyarakat secara langsung.

Pilar good governance harus ditegakkan, bukan saja oleh DPRD maupun lembaga pemerintah yang berkompeten di bidang pengawasan pembangunan, melainkan juga kontrol langsung oleh masya rakat, oleh karena itu, pendidikan politik bagi rakyat memegang peran kunci.

Penyelenggaraan pemerintah meru pakan variabel yang mempengaruhi kiner ja pemda, baik upaya legal and fair dalam meningkatkan PAD maupun pemampaatan anggaran.

Kerangka hukum yang efektif ada lah menjamin terselenggaranya good gover nance. Bila produk hukum tak mampu lagi tampil sebagai pranata pormal, maka hambatan struktural dan kultural dalam birokrasi daerah akan sulit dijinakkan. Pemerintahan yang baik dan bersih akan sangat urgen dalam konteks kewenangan pemungutan pajak dan retribusi.

Pembagian wewenang yang turn pang tindih (overlapping) berpeluang men ciptakan celah korupsi, juga membuat opti malisasi PAD tidak epektif. Secara teori tik, wewenang daerah untuk memungut pajak dan retribusi memiliki legitimasi yang kuat, dalam pemungutan pajak harus ada wewenang yang tegas antara pusat dan daerah.

\section{KESIMPULAN}

Otonomi daerah seyogianya lebih menekankan pada peranan pemerintahan yang efektif dan efisien dalam pembangunan ekonomi. Selain itu, daerah juga harus mengerahkan lebih banyak sumber daya dan terbuka terhadap kemungkinan ban tuan teknis untuk memerlancar reformasi kelembagaan dan pengembangan kapasitas perekonomian daerah.

Kita perlu memperbaharui kerang ka pikir (mindset) mengenai otonomi dae rah. Otonomi bukan hanya persoalan eko nomi dan politik, melainkan juga sosio kultural dan historic. Otonomi daerah bukanlah pembagian kue kekuasaan,

melainkan distribusi pertanggung jawaban pengelolaaan sumber daya pada public domain secara benar. Otonomi daerah bukanlah "tiket" bagi pemda untuk megeksploitasi potensi fiskal daerah, tetapi merupakan tugas dari

masyarakat setempat kepada pemerintahan untuk melakukan tugas pemerintahan dengan berorientasi pada public services.

\section{DAFT AR PUSTAKA}

Ismawan Indra, Ketimpangan Regional di Indonesia : Perspektif Ekonomi Politik Pondok Edukasi, Jakarta, 1995

------ , Ranjau-Ranjau Otonomi

Daerah, Pondok Edukasi, Jakarta, 1993 
Lubis Mochtar, Korupsi Politik, Jakarta, 1993

Masoed Mochtar, Birokasi Pemerintah Atas Barang dan Jasa, Gajah Mada Press, Yogyakarta, 1994.

Rachbini Didik J, Negara dan Kemiskinan di Daerah, Jakarta, 1995. Undang-Undang No. 32 Tahun 2004, Tentang Pemerintahan Daerah.

Undang-Undang No. 33 Tahun 2004, Tentang Perimbangan Keuangan Antara Pemerintah Pusat dan Pemerintahan Daerah. 